\title{
Klymenko $V$. \\ NUTRITION OF YOUNG CHILDREN AS A FACTOR OF HEALTHY NATION FORMATION
}

Kharkiv National Medical University, Ukraine

Head of Department of Fundamentals of Pediatrics İNo.2

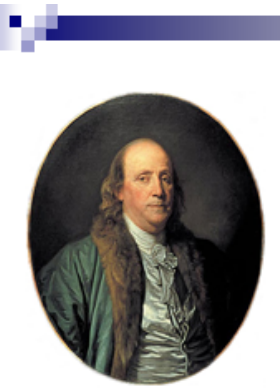

"A human lives not by what he eats, but by what he digests.

This is equally true for both his mind and body".

Benjamin Franklin

The formation of the "mind" is a highly complex and sometimes unpredictable process and we as university pedagogues are well aware of that. The formation of the "body" is a simpler goal which may be achieved based on the knowledge of physical development principles. One of the main factors determining the physical wellbeing is nutrition.

Over the recent years our perception of the role of nutrition in a person's health

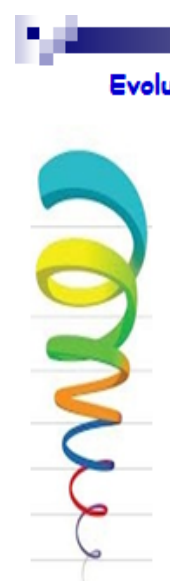
and wellbeing have underwent significant changes. Common people know the correlation between the parameters of physical development - Phenotype = genotype + environment The cause of non-infection "epidemics" like obesity, diabetes mellitus type II, asthma, hypertension, stroke, infarcts etc.

(body weight, waist and thighs circumference) and the quality and

- A factor determining the characteristics of physical development quantity of food.

Starting from the second half of the XX century, after the elimination of numerous infectious diseases such as the plague, smallpox, poliomyelitis and others one may observe a rapid spread of non-infectious diseases: obesity, type 2 diabetes, asthma, cardiovascular diseases, strokes, heart attacks etc. According to WHO data, 
over 36 million people die from those illnesses annually. Scientific findings show that nutrition is one of the factors responsible for the pandemic of those diseases. The slogan "phenotype equals genotype plus environment (including nutrition)" is most often used to describe the pathogenesis of the said diseases.

The beginning of the XXI century brought a new understanding of the role of nutrition, which today is seen as an "epigenetic factor".

\section{Randy Jirtle and Robert Waterland experiment, 1999 as elassical epigenetics}

- The scientists did their research with Agouti (Avi) Yellow mice.

- The Agouti gene - yellow coloring, obesity, diabetes, cancer.

- Pregnant females fed with choline, betaine, folic acid and vitamin B12 started giving birth to healthy offsprings with normal coloring and lifespan.

- The effect of the Agouti gene was erased completely, although not a single DNA nucleotide of any mouse had been changed.

"Tansposable elements: targets tor early nutritional eftects on eppgenetc gene regulation"

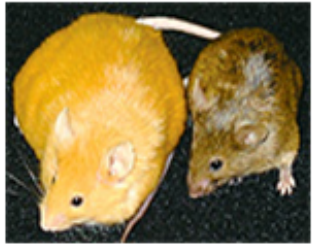

The experiment of Professor Randy Jirtleand AND his postdoc Robert Waterland from the Duke University (USA) serves as a scientific proof of the epigenetic role of nutrition. They bred transgenic Agouti mice named after the homonymous gene integrated into their genome. The said gene determined not only their yellow coloring and excessive body weight, but also their aptitude for cancer and diabetes. In normal conditions these rodents throw similar offsprings: yellow, obese and sickly. However, the scientists managed to get a healthy breed with normal coloring and lifespan. The Agouti gene effect was fully erased, although not a single DNA nucleotide of the mouse was altered. This happened only due to the fact that before the birth of the new breed the diet composition of females had been changed - they received food enriched with methyl group elements (choline, betaine, folic acid and vitamin B12). These elements can be found in fruits and vegetables, inter alia onions, garlic and beet.

This is how Randy Jirtle commented his findings in his article "DNA is not destiny" for "Discovery" journal: 
口

DNA Is Not Destiny:

The New Science of Epigenetics

Discoveries in epigenetics are rewriting

the rules of disease, heredity and identity

"We commonly accept the notion that through our DNA we are destined to have particular body shapes, personalities, and diseases. Some scholars even contend that the genetic code predetermines intelligence and is the root cause of many social ills, including poverty, crime, and violence. "Gene as fate" has become conventional wisdom. Through the study of

epigenetics, that notion at last may be proved outdated.

Suddenly, for better or worse, we appear to have a measure of control over our genetic legacy. Epigenetics is proving we have some responsibility for the integrity of our genome. Before, genes predetermined outcomes. Now everything we do everything we eat or smoke - can affect our gene expression and that of future generations. Epigenetics introduces the concept of free will into our idea of genetics."

The epigenetic role of nutrition is particularly significant prior to birth and in the first years after childbirth.

Scientific data on the epigenetic role of nutrition served as prerequisite for establishing the International program "1,000 Days Partnership" which was opened in September, 2010 with the support of US Secretary of State Hillary Clinton, the Minister for Foreign Affairs of Ireland and the community of world leaders.

The program supports all aspects of scientific, economic and public activity which increase the awareness regarding the importance of proper nutrition of pregnant women and infants and are aimed at combating famine. As of now over 80 organizations are taking part in the program.

\section{Project «Early Life Nutrition» in Ukraine}

\section{NUTRITIONAL DEFICIENCIES IN CHILDREN UNDER THE AGE OF 3 IN UKRAINE}

Lviv National Medical University - prof. Nyankovskyy S.L. Institute of Pediatrics, Obstetrics and Gynecology of National Academy of Medical Science of Ukraine - prof. Shadrin O.G. Kharkiv National Medical University - doc. Klymenko V.A.,
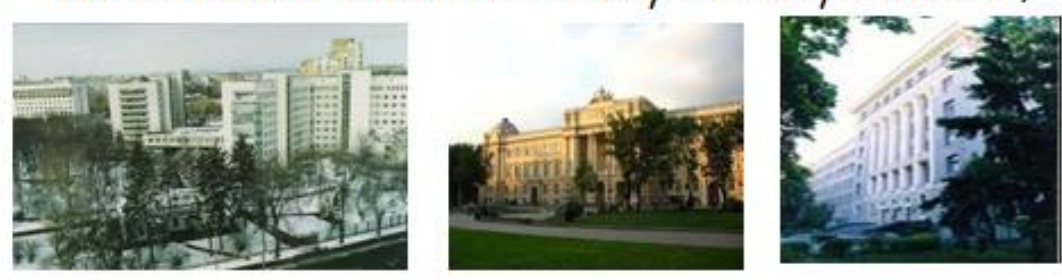

A major project "Early Life Nutrition" was launched in February, 2012. The participants include researchers from 36 institutions situated in 15 
countries in Europe, the USA and Australia. The project is aimed at studying the effects of nutrition programming in a person's life. The project is coordinated by Doctor of Sciences, member of the ESPGHAN (The European Society for Paediatrics Gastroenterology Hepatology and Nutrition) committee on the issues of nutrition, Professor B. Koletzko.

In 2013-2014 Ukraine proceeded to implement the program "Early Life Nutrition". In particular, a research on evaluating the nutrition of young children was conducted with the participation of the State "Institute of Pediatrics, Obstetrics and Gynecology of National Academy of Medical Science of Ukraine”, Kharkiv National Medical University and Lviv National Medical University.
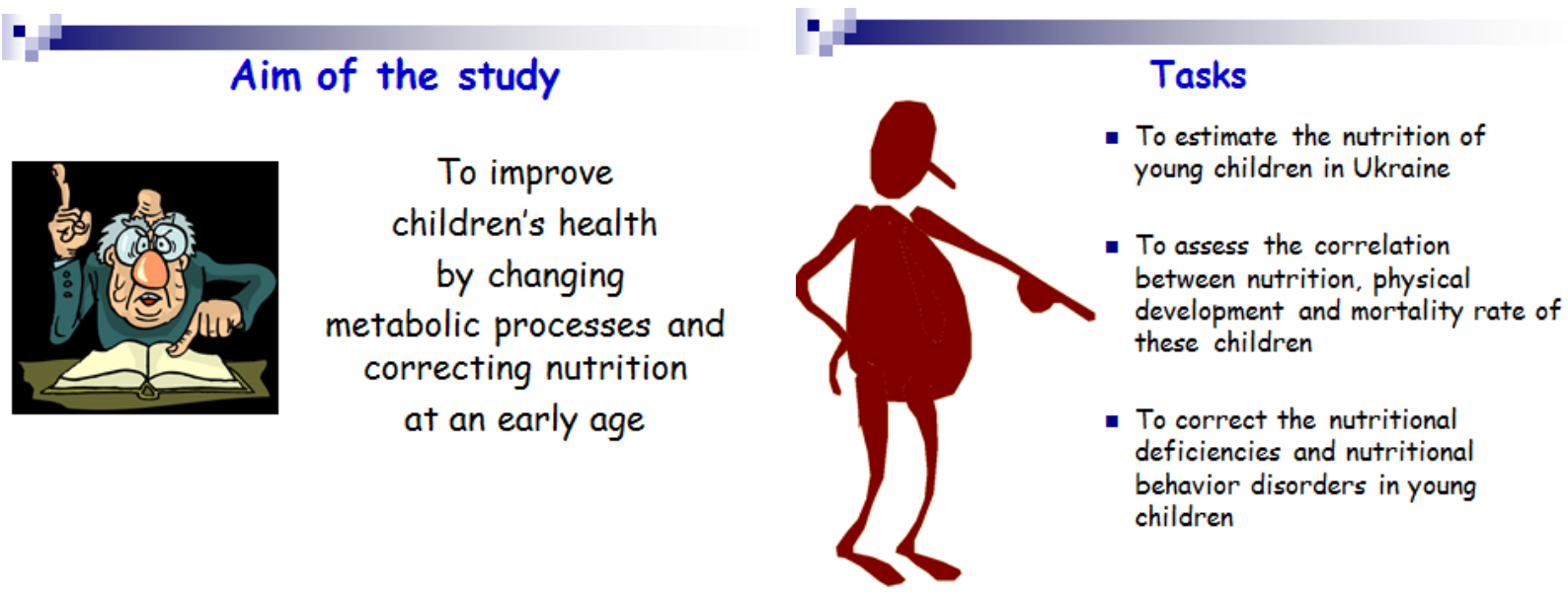

The diet of 350 children aged from 9 months to 3 years in different regions of Ukraine (center - Kyiv, west - Lviv, east - Kharkiv) was studied. In Kharkiv 116 children were examined. Parents of every observed patient kept a diary indicating three daily nutritional rations ( 2 workdays and 1 off-day). Every family received electronic scales and parents precisely measured and documented the weight and name of consumed product. If a mother fed the child with a self-prepared dish such as borsch, the accurate weight of the ingredients was indicated and then the exact weight of one portion of the product was calculated.

Thenutritionalvalueofthedietwasdeterminedaccordingtothespecialprogram "Dietplan 6" (Great Britain), which takes into account the content of all the basic nutrients in the products. The Recommendations of the Committee of Medical Aspects of Food Policy (1991) were taken as a norm. 


\section{Materials and methods}

- The nutritional value of the diet was determined according to the special program "Dietplan 6" (Great Britain)

- The following parameters were calculated:

- daily amount of calories

- amount of the proteins, fats and carbohydrates

- macronutrients (calcium, phosphorus, potassium. magnesium)

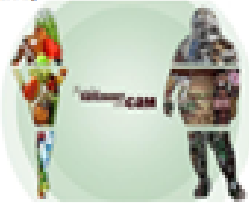

- essential micronutrients (iron, zinc, iodine, fuorine, copper, selenium. chromium, molybdenum, cobalt and manganese)

- vitamins (A, D, E, B1, B2, B6, B12, C, folates)

- The reference values of consuming nutrients and calories of nutritional products were interpreted pursuant to the recommendations of the Committee of Medical Aspects of Food Policy (1991)

- Blood was drawn from 105 children to determine the level of

- ferritin

- transferrin

- erythrocytes

- hemoglobin

- hematocrit

- The analysis was performed on analyzer "Cobas 6000" with test-system Roche Diagnostics (Switzerland) in laboratory «Sinevo"

- Statistical methods

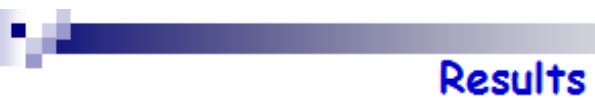

Quantitative analysis of the main nutrients

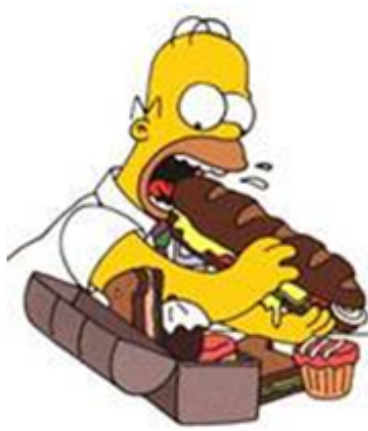

- Exceed the norms

$\square$ Proteins

$\square$ Carbohydrates

$\square$ Energy (kcal)

- Meet the norms

$\square$ Fats 


\section{Results \\ Energy}

- Average energy intake per day - 1165,67 [290,67 4951,33] keal

$\square$ Norms of WHO, EU, the USA $\approx 1000 \mathrm{keal} /$ day

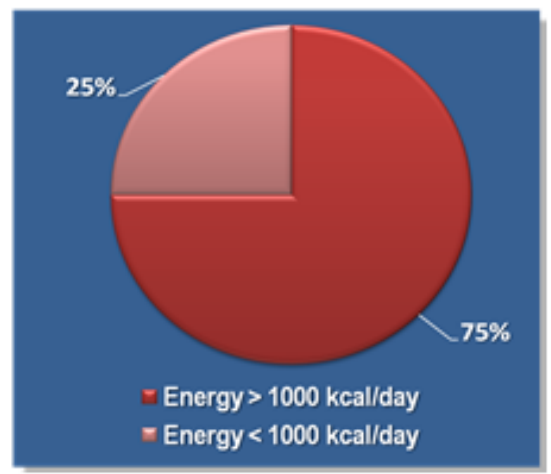

-

\section{Results}

Consumption of protein

- Average consumption per day 40,53 g [0,63 - 230,37]

$\square$ Norms of WHO, EU, the USA $\approx 13$ r

$\square$ Ukrainian norms- 53 r

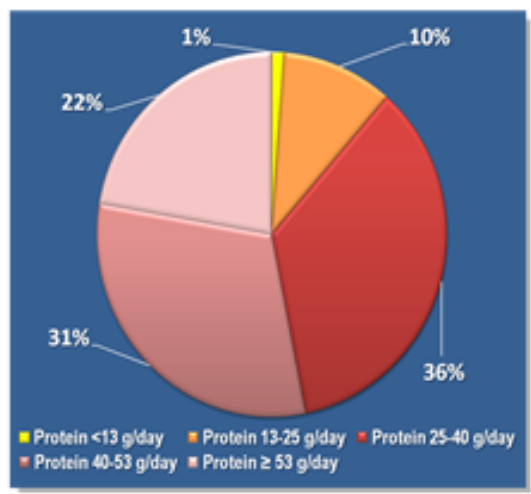

$\square$

\section{Results}

Macro- and microelement consumption

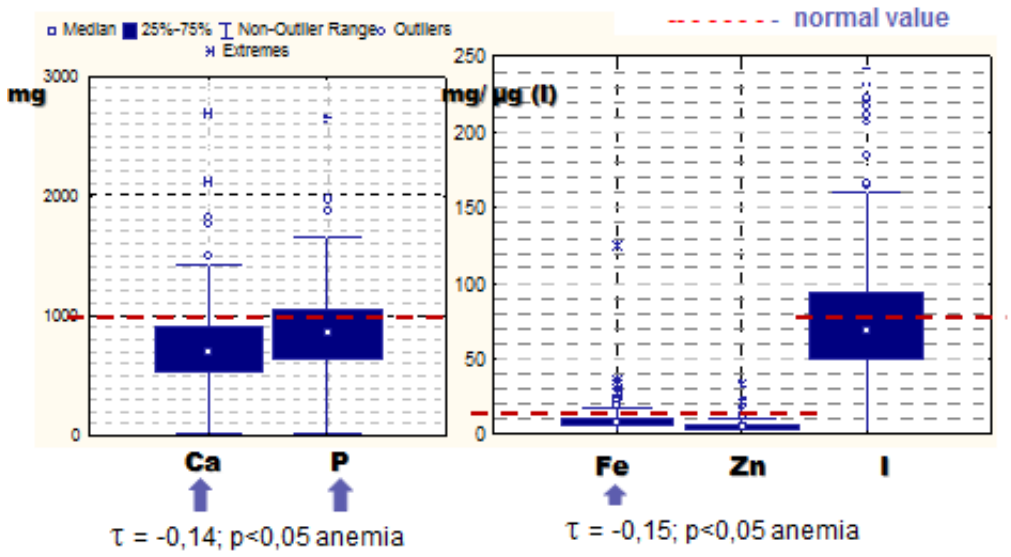


-

Results

Percentage of children with deficiencies in basic minerals in their diet

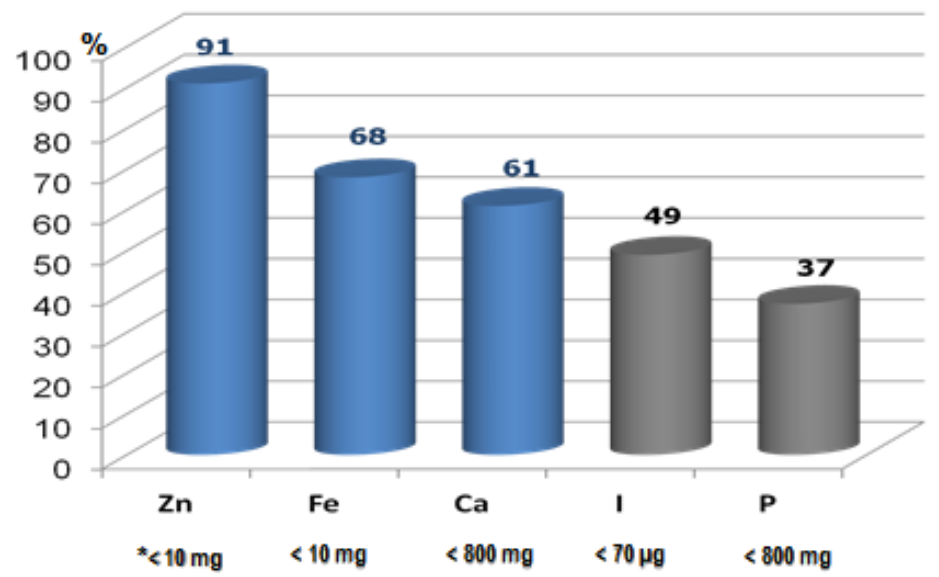

\section{Results}

Vitamins consumption

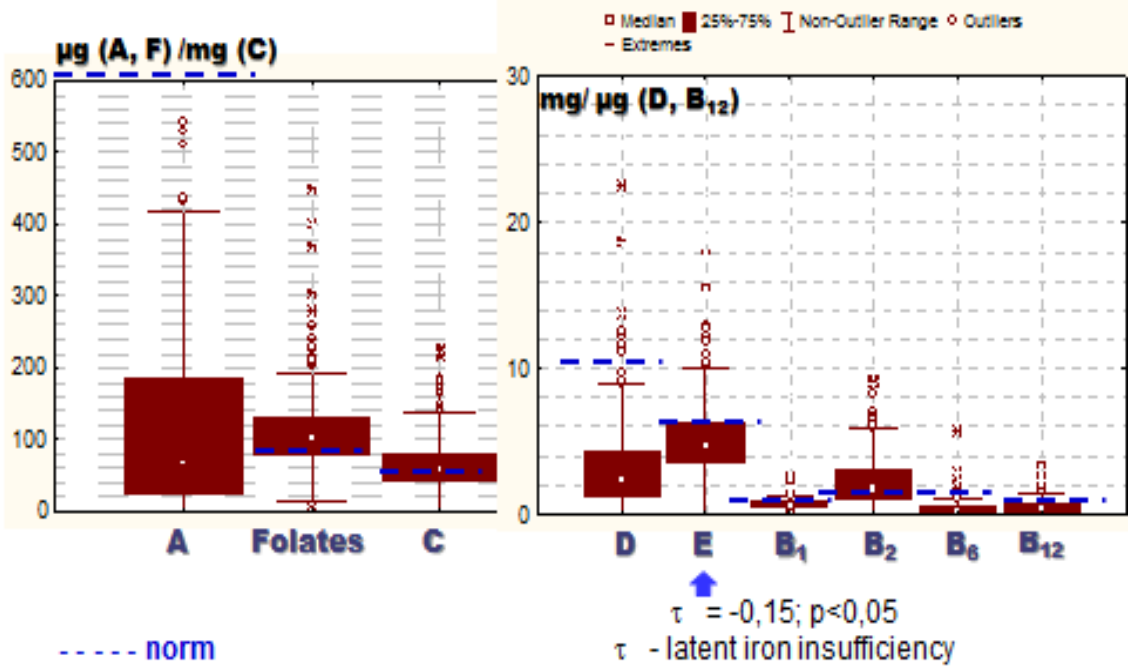

Results

Percentage of children with deficiencies in

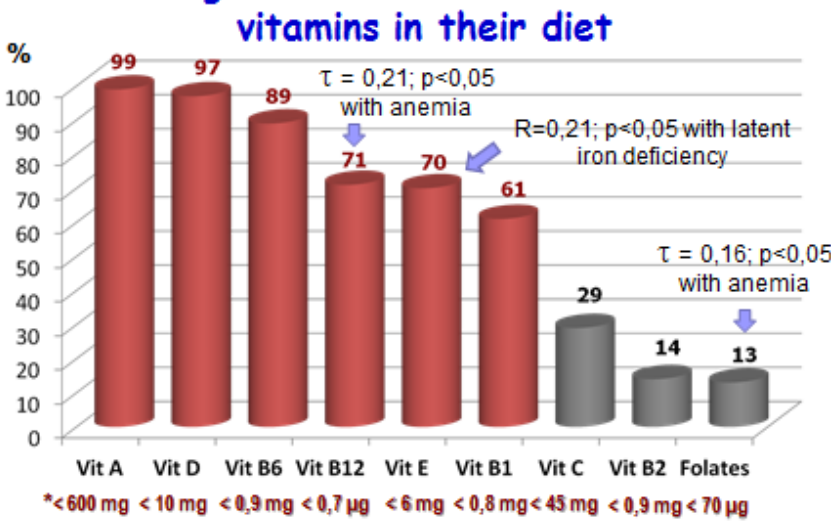


Comparative frequency of breastfeeding, formula nutrition and other dairy products (cow milk, yoghurt) when participating in the research depending on the age of a child

9-12 mo.

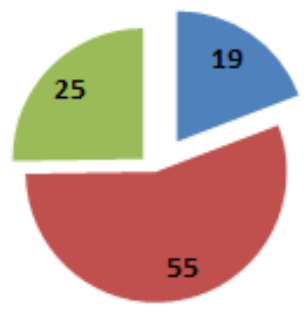

12-24 mo.

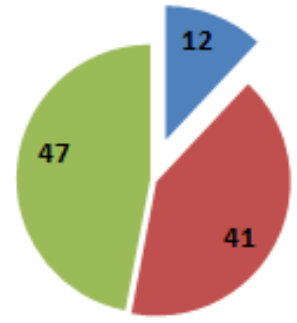

24-36 mo.

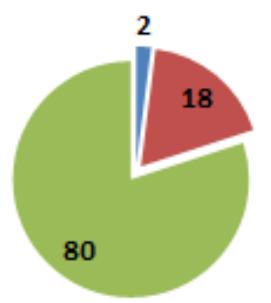

Breast feeding

Adapted milk formula

Other dairy products

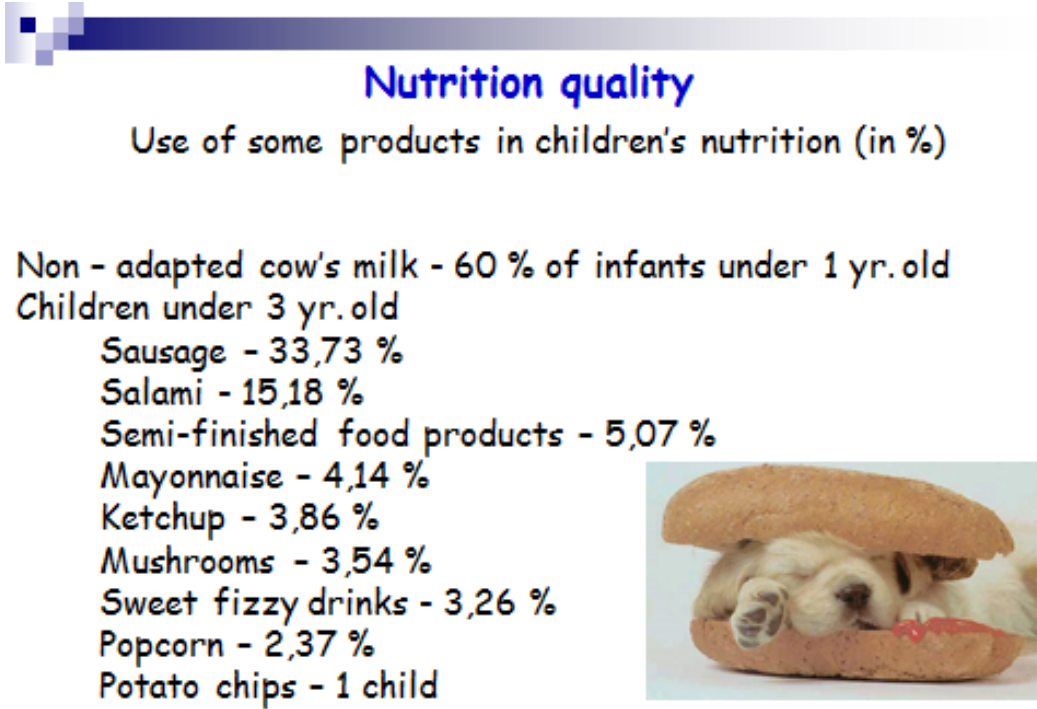

-

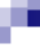

\section{Results \\ Iron consumption and iron-deficiency anemia}

\section{Iron-deficiency anemia - $4,8 \%(95 \% \mathrm{Cl} 2,07-10,76 \%)$}

- Latent iron deficiency $47,12 \%(95 \% \mathrm{Cl} 37,8-56,64 \%)$

- Low iron consumption $68,29 \%(95 \% \mathrm{Cl} 63,23-72,94 \%)$

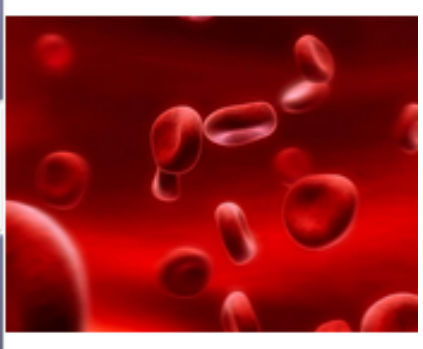

\begin{tabular}{|c|c|c|}
\hline Country & Iron-deficiency anemia (\%) & Iron deficiency \\
\hline USA (12-35 month) & 2,1 & 9,2 \\
\hline Russia & $\mathbf{2 3 - 4 3}$ & $\mathbf{8 0 - 9 0}$ \\
\hline
\end{tabular}




\section{Results}

Physical development of young children in Ukraine

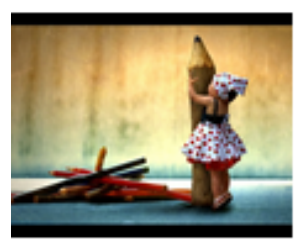

$\square$ Low body mass index - $17(5,09 \%)$

$\square$ High body mass index - $62(17,71 \%)$

$256(73,14 \%)$ children weight more than the established average for their age

The stable correlation between nutritional mineral/vitamin defieiency and childhood diseases

\begin{tabular}{|c|c|c|c|c|c|}
\hline Disease & $\begin{array}{l}\text { Nutritional } \\
\text { deficiency }\end{array}$ & $\begin{array}{l}\text { Spearman's rank } \\
\text { correlation } \\
\text { coefficient }(R)\end{array}$ & $p(\mathrm{R})$ & $\begin{array}{l}\text { Correlation } \\
\text { coefficient' } y\end{array}$ & $p(\gamma)$ \\
\hline $\begin{array}{l}\text { Respiratory } \\
\text { infections }\end{array}$ & $\begin{array}{l}\text { Vitamin D } \\
\text { Zink } \\
\text { Vitamin } B_{6} \\
\text { Vitamin C }\end{array}$ & $\begin{array}{l}0,14 \\
0,14 \\
- \\
-\end{array}$ & $\begin{array}{l}0,009 \\
0.008 \\
- \\
-\end{array}$ & $\begin{array}{l}0,74 \\
0,44 \\
0,28 \\
0,19\end{array}$ & $\begin{array}{l}0,0003 \\
0,0002 \\
0,008 \\
0,008\end{array}$ \\
\hline $\begin{array}{l}\text { Gastrointestinal } \\
\text { infections* }\end{array}$ & $\begin{array}{l}\text { Iron } \\
\text { Vitamin } B_{1} \\
\text { Zink } \\
\text { Vitamin } B_{6}\end{array}$ & $\begin{array}{l}0,14 \\
0,11 \\
- \\
-\end{array}$ & $\begin{array}{l}0.01 \\
0.03 \\
- \\
-\end{array}$ & $\begin{array}{l}0,53 \\
0,39 \\
0,58 \\
0,65\end{array}$ & \begin{tabular}{|l}
0,0001 \\
5 \\
0,002 \\
0,04 \\
0,015 \\
\end{tabular} \\
\hline Allergic diseases & Vitamin $B_{6}$ & - & - & 0.26 & 0.04 \\
\hline
\end{tabular}

* - the quantity of infection outbreaks in the anamnesis

\section{Conclusions}

- The contemporary diet of young children in Ukraine is unbalanced, contains a surplus of energy and proteins, but nonetheless provides insufficient amounts of numerous minerals and vitamins. Such insufficient diet may result in physical development disorders (primarily overweight) and an increase in mortality rate due to infections.

- Zinc, iron, calcium, vitamins $A, D, E, B_{6}, B_{12}$ and $B_{1}$ deficiencies turned out to be the most significant.

- Statistically meaningful associations were established between nutritional deficiencies, iron-deficiency anemia and children mortality rate. 
The results were published:
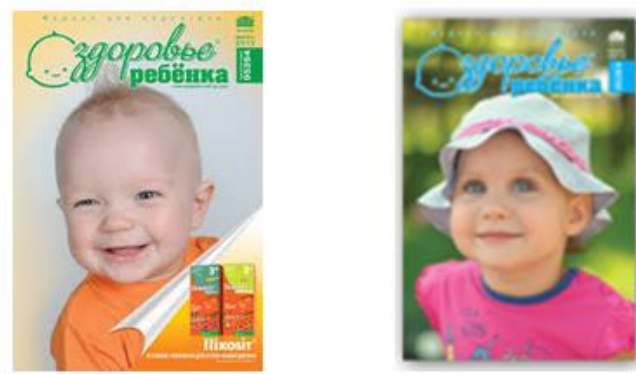

2 articles in the journal "The child health" (Ukraine)
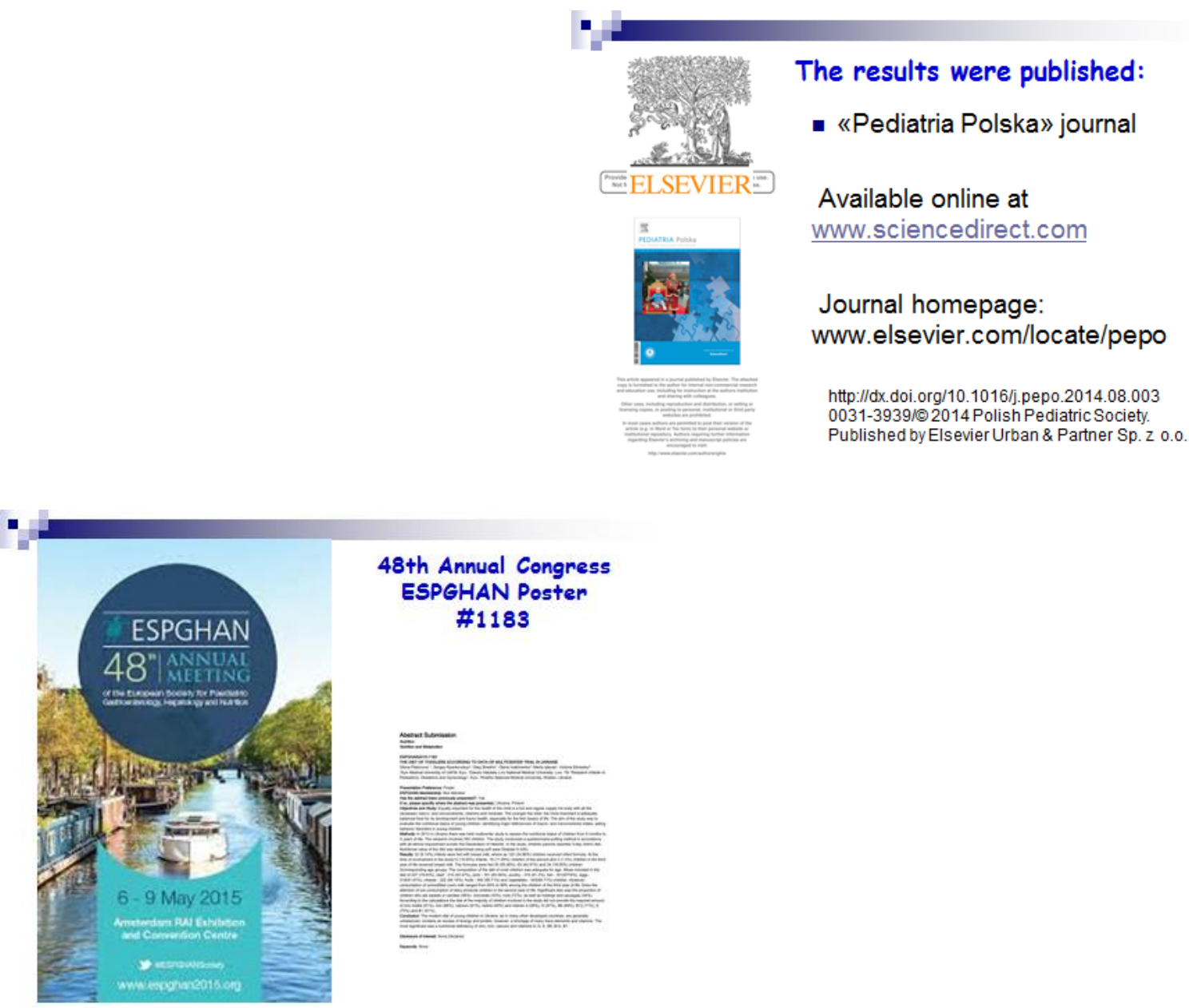
48th Annual Congress ESPGHAN Poster
\#1183

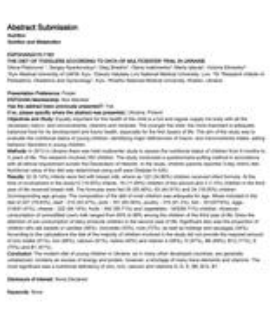

\section{Practical Implementation}

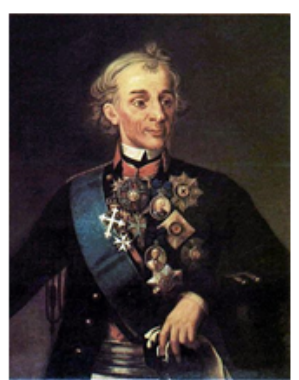

Practice without theory

is blind,

but theory without practice

is dead.

Alexander Vasilyevich

Suvorov 
Methodical recommendations regarding nutrition of young children

In collaboration with:

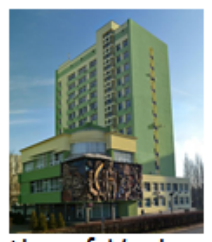

Institution of Hygiene and Medical Ecology named J.M. Marzeev of National Academy of Medical Science of Ukraine Laboratory of Food Hygiene

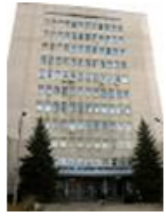

Kharkiv Medical Academy of Postgraduate Education

Department of Children Gastroenterology and Nutriciology (Prof. Belousova O.Ju.)

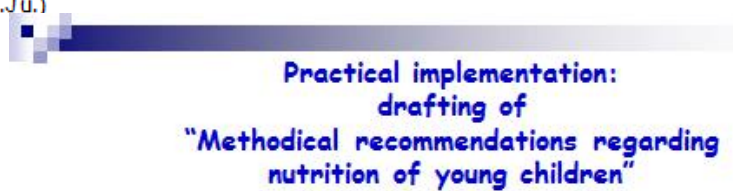

utrition of young children

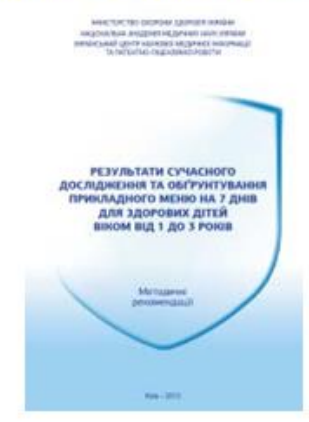

\section{Perspectives}

- 2014 - the establishment of the Expert Council

"Nutrition for a new life"

- Meetings of the Council:

$\square$ Eastern Region - Truskavets, 14.06.2014

$\square$ Western Region - Dnepropetrovsk, 20.06.2014
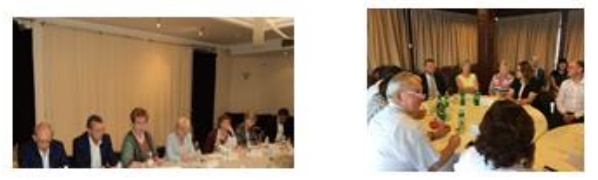

The heads of pediatric departments of the majority of medical universities of Ukraine participated in the expert council meeting. Every participant with regard to the clinical basis and resources of the department outlined the further perspectives of participating in the "Nutrition for a new life" program (a Ukrainian variant of "Early Life Nutrition"). 


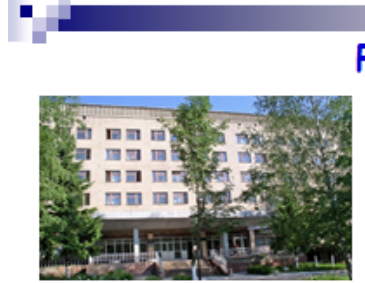

\section{Perspectives}

The main topic of scientific research (years 2014-2017) of the Department of Fundamentals of Pediatrics iNo.2 of

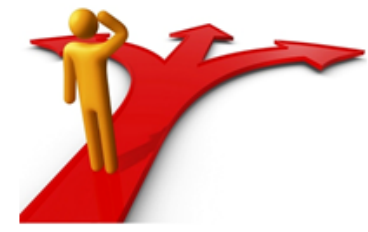
Kharkiv National Medical University is problem of food allergy (cow's milk protein) in young children

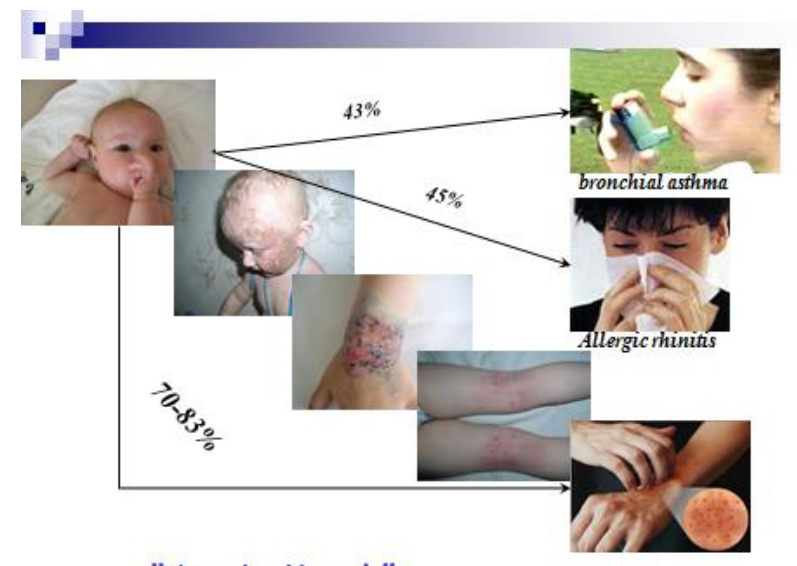

"Atopic Match"

The relevance of the chosen line of research is determined not only by prevalence of cow's milk protein allergy but also by the scientifically proved possibility if not to seize but at least to modify the formidable atopic march.

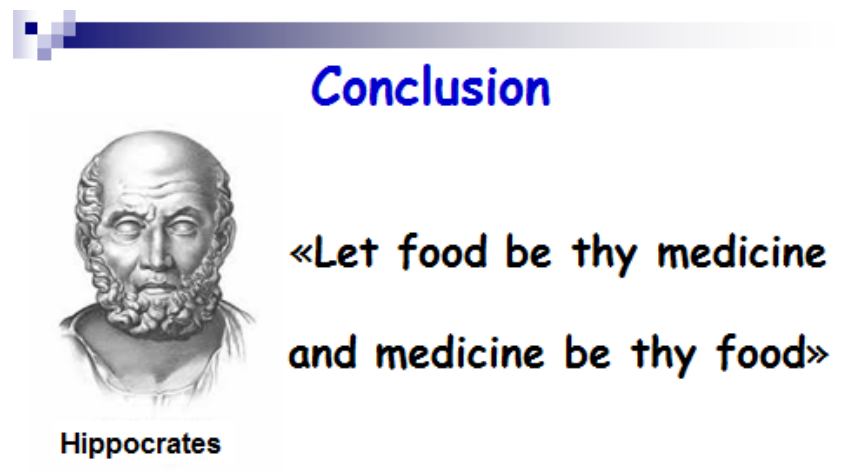

